\title{
School democratization in prefigurative form: two Brazilian experiences
}

Tristan McCowan, Institute of Education, University of London

Published in Education, Citizenship and Social Justice, 2010, Vol. 5 (1), 21-41.

\begin{abstract}
Recent moves towards greater pupil participation in school decision-making have in part been based on instrumental rationales, such as increases in test scores and improvements in behaviour. This article assesses a different approach -- that of the 'prefigurative' -through which the school embodies the democratic society it aims to create. Two examples of prefigurative initiatives in Brazil are assessed: the Landless Movement, a social movement for agrarian reform that runs a large network of schools in its rural communities, and the Plural School, a framework of social inclusion in the municipal education system of Belo Horizonte. Qualitative case studies of the two showed significant enhancement of the democratic culture of the schools and changes in the teacher-student relationship. However, a number of problematic issues were also raised, including the difficulties in extending participation to the whole student body, and the tensions with teachers when students began to exert greater influence in school. Finally, the implications of these prefigurative cases for an understanding of education for democratic citizenship are drawn out.
\end{abstract}

\section{Keywords}

Brazil; citizenship education; democratic education; prefigurative; pupil participation

\section{Introduction}

The idea that pupils should participate in school decision-making has gained considerable credence in recent years, and there have been some corresponding changes in policy and practice. In the UK, school councils in particular have become more commonplace, and although the Crick Report (QCA 1998) stops short of making them obligatory, it does provide them with a strong endorsement. However, the rationales on which this participation is based differ significantly. Participation can be seen as a right of the child or young person, as enshrined in 1989 by the United Nations Convention on the Rights of the Child (Lundy 2007; McEvoy and Lundy 2007; Osler and Starkey 2005). Yet there are 
a number of other instrumental justifications. Pupil participation has been linked to 'school effectiveness' and 'school improvement', increases in test scores, improvements in the behaviour of pupils, and enhancing the overall ethos of the school (Flutter \& Ruddock 2004; Harber \& Trafford 1999; Macbeath \& Moos 2004) ${ }^{1}$. Pupil 'consultation' is also seen as a way of improving research on schools and thereby of improving the quality of schooling (Ruddock \& Flutter 2000).

The rationales outlined above are characterised by an extrinsic value given to participation, in relation to the educational and other benefits it brings to individuals and institutions. However, participation can also be supported from the standpoint of its intrinsic democratic value (Maitles \& Deuchar 2006; Cox \& Robinson-Pant 2006). Democratic structures in schools, from this perspective, are a good in themselves, whether or not they contribute to the performance of students academically or socially. At the same time they are also seen to be means by which students can develop knowledge, skills and values related to democratic participation outside the school.

The particular rationales underlying pupil participation are significant because they affect the nature of the experiences provided for students, the extent to which they are integrated into the curriculum as a whole, and the ways they are linked to political processes in the wider society. Moves towards democratisation of schooling in countries like the UK have been at best tentative, and at worst tokenistic (Maitles \& Deuchar 2006). Research on school councils in the UK context has shown some positive effects for the students involved, but with discussions usually limited to uncontroversial areas (Baginsky 1999; Inman \& Turner 2007; Taylor 2002). As Ruddock and Flutter (2000: 83) state:

If the school is not ready for pupil participation then a school council can become a way of formalising and channelling students' criticisms; an exercise in damage limitation rather than an opportunity for constructive consultation. And the agenda of schools councils often do not roam far outside the charmed circle of lockers, dinners and uniform.

Researchers such as Cox and Robinson-Pant (2006) have shown ways in which the democratic nature of these councils can be enhanced, but there remains the question of the extent to which democratisation can occur within the hierarchical and nonparticipatory backdrop of the education system as a whole.

There are, however, a number of examples of more substantially democratic initiatives. Experiments like Summerhill School in England, the Democratic School of Hadera in Israel and Kohlberg's "Just Community Schools" in the USA have, on a small scale, succeeded in bringing high levels of pupil involvement in decision-making in relation to all aspects of school (Gribble 1998; Power et al. 1989). Apple and Beane (1999) also identify significant contemporary cases of democratic experiences in mainstream schools in the USA. In contrast to private schools like Summerhill, these are located in or serve disadvantage communities, and therefore face an uphill struggle in terms of school democratisation. The schools see participation not just in terms of pupils having their say, 
but also in terms of identification with and working for the common good. Importantly, enhanced student involvement is accompanied by increased democratic participation of teachers and the community. Democratisation manifests itself not just in participatory bodies, but in changes to pedagogy and the curriculum:

These are not merely abstract principles, but are woven into the curriculum and teaching practices of the schools. The practices themselves involve a negotiated curriculum, extensive community and student involvement, and flexible forms of assessment. (p. x)

However, democratic experiences such as these are generally confined to specific schools or school districts in which committed teachers and community members have succeeded in carving out a degree of autonomy from prevailing norms. The vast majority of schools in countries like the USA and UK have not as yet moved beyond the 'thin' democratisation of the student/school council.

This article explores participatory approaches to schooling based in an intrinsic valuing of democracy. Specifically, it focuses on the 'prefigurative' approach. Prefigurative forms of political organisation are those which reflect the qualities of the ideal society aimed for. In relation to school, therefore, prefigurative forms require a 'harmony' between the democratic nature of the institution and the democratic society to be constructed (McCowan 2008; 2009). Prefigurative forms differ from other approaches giving intrinsic value to democratic structures in that they have an explicit commitment to the creation of a new form of society, rather than solely preparing citizens for effective participation in the current one. Two cases of school democratisation in Brazil - the Landless Movement and the Plural School - are analysed in order to explore the possibilities of these prefigurative forms. While these experiences encounter significant problems in relation to implementation, they represent important instances of participatory approaches.

Before introducing the initiatives in question, there will first be a more detailed discussion of the notion of the 'prefigurative'.

\section{Prefigurative forms}

Boggs (1978: 2) defines prefiguration as, "the embodiment, within the ongoing political practice of a movement, of those forms of social relations, decision-making, culture and human experience that are the ultimate goal". An initial distinction needs to be made between this meaning of 'prefigurative', and another, stemming from the anthropological work of Margaret Mead. In the latter, a distinction is made between postfigurative, where younger generations learn from older ones, cofigurative, where people learn from their peers, and prefigurative, where older generations learn from younger ones. This use of the term is seen in educational theory in the case of Li (2005), for example. However, in this article, the term is employed following its usage in political theory to signify the 
ways in which forms of organisation embody, reflect or model the ideal society they wish to bring into being.

Historically, prefigurative movements developed in opposition to forms of Marxism -most notably Leninism -- that looked to a revolution headed by a strong party as the most effective way of achieving the goal of the socialist society. In these consequentialist forms, the means were in tension with the ends, in that hierarchical organisation and violence were used to achieve a peaceful, non-hierarchical society. In contrast, other forms of revolutionary organisation aimed to embody the values of the desired society within their political activities, with "the pursuit of utopian goals...recursively built into the movement's operation and organisational style" (Buechler 2000: 207). Boggs (1978: 5) identifies three basic concerns within the prefigurative tradition: an opposition to hierarchical relations of authority; criticism of centralised political organisations that reproduce these types of power relations; and a "commitment to democratisation through local, collective structures that anticipate the future liberated society".

Prefigurative forms are commonly associated with anarchist movements, and represent a pillar of anarchist thought (Franks 2003, 2006; Suissa 2006; Ward 1982). Gordon (2005b) states:

Anarchist modes of interaction -- non-hierarchical, voluntary, cooperative, solidaric and playful -- are no longer seen as features on which to model the future society, but rather as an ever-present potential of social interaction here and now. Such an approach promotes anarchy as culture, as a lived reality that pops up everywhere in new guises, adapts to different cultural climates, and should be extended and developed experimentally for its own sake, whether or not we believe it can become, in some sense, the prevailing mode of society.

The author refers to this as 'present-tense' politics, with revolution not "a horizon event, but an ongoing process".

Although incorporated in a variety of forms of organisation such as worker writers' groups (Woodin 2007) and anti-nuclear campaigns (Epstein 1988), it is perhaps feminist movements have been the most prominent examples of prefigurative politics in recent times. Rowbotham (1979) points to consciousness-raising and self-help groups as examples in which close attention was paid to forms of relationship developed in meetings:

They do not assume that we will one day in the future suddenly come to control how we produce, distribute and divide goods and services and that this will rapidly and simply make us new human beings. They see the struggle for survival and control as part of the here and now. (p.140)

Rowbotham, and other feminist writers such as Evans (1979), Breines (1982) and Epstein (1991; 1988), point to the importance not just of changing ideas, but of actually 
experiencing non-exploitative relations. This is related to the linking of the private and the public spheres in the concept of citizenship, and the idea that 'the personal is the political'.

The literature on prefigurative political organisation is predominantly associated with 'left-wing' movements, but the notion is not restricted to a particular political orientation: movements and institutions can prefigure conservative or fascist ideals too. The essential component is that there is a modelling or consonance between the prefigured and the prefigurative. As Gordon (2005a) points out, the prefigurative is not an independent value: whether or not it is a good depends on what is being prefigured.

The fact that that prefigurative forms are developed "for their own sake" (Gordon 2005b), raises some important questions concerning ends and means. It is possible to draw a distinction between the derivation of educational means from ends on the basis of different rationales: empirical evidence, tradition or authority, moral imperative or logical connection (McCowan 2009). Of these, the prefigurative indicates a 'moral imperative' rationale. Prefiguration can never be a purely strategic venture (Breines 1982): it cannot simply be abandoned in favour of a more effective strategy, since it is not only a means but also an instantiation of the end in the present.

Another important aspect of the prefigurative is to act as an exemplar, given that an effective way of disseminating ideas is to show their working in practice. In addition, prefigurative forms are not only instrumental to the transformation of society, but also for personal liberation (Gordon 2007), providing important informal learning experiences for those involved, both individually and collectively. It is also possible for formal education to be prefigurative. An example of this is the 'People's Education' in South Africa during the apartheid struggle (Wolpe 1991), where the educational processes were linked to the wider processes of social transformation of the time. Michael Fielding's (e.g. 1997; 2007) work on radical state schooling also draws extensively on the idea of the prefigurative. In fact, he sees these school experiences as being at the forefront of experimentation in democracy:

This anticipation of future modes of being through processes and relations, not just structures, that exemplify and embody the viability and desirability of radical alternatives is one of the most important past and continuing contributions of the radical traditions of state education to the furtherance of democracy in this country. (Fielding 2007: 544)

The author provides the example of St. George-in-the-East Secondary School in London, led from the 1940s by the pioneering head teacher Alex Bloom, which developed innovative democratic practice in relation to curriculum and assessment, as well as dayto-day school management.

In addition to the element of rationale mentioned above (McCowan 2009), a distinction can also be made in relation to the proximity of ends and means - the extent to which they exist in a relationship of separation, harmony or unification with one another. 
Prefigurative political organisations show 'unification' mode, as political learning occurs through the act of political participation itself. Prefigurative types of formal education are in 'harmony' mode, as the values underlying the educational processes are in accordance with those of the ideal society. From another perspective, however, even a formal educational experience could be said to show unification, as it can be seen as an actual instantiation of the political action, as well as a preparation for it.

It is therefore possible to identify three key functions of prefigurative forms. They constitute:

1) An instantiation of the new society

2) A learning process for those involved

3) An exemplar of alternative forms of organisation

There is a hierarchy between these three aspects. Instantiation - the realisation of the ideal society in the present - is the most important aspect of prefigurative forms, and they need no other justification. Learning is an instrumental justification, but is highly important as social transformation depends on the development of new forms of living. A key point of the prefigurative, therefore, is that it is simultaneously preparation and realisation, learning and action. Lastly, exemplification is an important side-effect of the process, allowing people to see that alternatives are possible.

There will now be an analysis of the ways these prefigurative forms are expressed in the two empirical cases.

\section{Two Brazilian experiences}

The two cases analysed in this article have contrasting characteristics, yet they share the feature of being part of the wave of democratisation that occurred in Brazil after the military dictatorship of 1964-1985. Education is an area in which there has been particularly strong mobilisation and debate in the contemporary period. Social movements, community groups, NGOs, church groups and local governments have all been active in constructing and implementing educational alternatives (Bartlett 2005; Fischer \& Hannah 2002; Gandin 2006; Gentili \& McCowan 2003; Ghanem 1998; KingCalnek 2006; Myers 2008). These developments in education have been strongly influenced by the work of Paulo Freire $(1972 ; 1994)$, particularly his ideas of 'dialogue' and 'conscientisation', and the emphasis on the link between the educational and political. The decentralised nature of the Brazilian system has meant that opposition to dominant paradigms has not only taken the form of pressuring central government for policy changes, but also that of actively constructing alternatives at the local level. A number of significant local government initiatives have emerged in the last 20 years, most under municipal (and to a lesser extent state) governments of the Workers' Party (PT), which have been motivated by the active support of teachers and local 
communities. The first of the cases discussed in this study, the Plural School, is a local initiative of this type, while the second, the Landless Movement, is the most influential of the social movements emerging since the dictatorship.

These two cases were chosen on the basis of their intrinsic significance and because of their use of the prefigurative forms of interest to this study. While the MST is a national initiative, the study chose to focus on its work in one region, the state of Rio Grande do Sul. This state - the southernmost in the country, with a strong rural tradition - was the location for the founding of the movement, and is still a key locus of its activity. Previous research carried out on education in the MST (McCowan 2003) focused on the states of Bahia and Espirito Santo. While the findings of the previous study will be drawn on, this article will focus on the data collected in Rio Grande do Sul in 2005-2006.

Qualitative research was carried out, involving three forms of data collection: documents, interviews and observations. For each initiative, in addition to a general overview, two schools where chosen for in-depth research ${ }^{2}$. Documents collected included official curriculum statements and pedagogical materials at national, state and school levels. In each case, interviews were conducted with three coordinators or officials, and, in the focus schools, with the head teacher, three classroom teachers, and three groups of students aged 13-17. Interviews were conducted and transcribed in Portuguese (quotations appearing in this article have been translated into English by the author). Classroom observations were also carried out, and field notes taken of experiences in the school as a whole.

There are many aspects of interest in these initiatives, but this article will focus on just one of these -- approaches to pupil participation in schools. Neither of the two cases uses the language of the 'prefigurative' explicitly. However, they clearly display a commitment to this form of organisation in both their writings and practice. For each case there will be an overview of the initiative, followed by an outline of its approach to pupil participation and assessment of its implementation in practice.

\section{The Plural School}

The Plural School (PS) is an initiative of the municipal government of Belo Horizonte, a large city with a metropolitan area of over 5 million inhabitants. The city is capital of Minas Gerais, a large land-locked state at the centre of Brazil, one of economic and political significance in the history of the country. While the region is wealthy in comparison to the North and North-East of Brazil, there are severe inequalities leaving a significant proportion of the population in poverty and political marginalisation. A disproportionate part of this group is made up by the Black and mixed-race communities, many descendants of the slaves who were brought to the region during the gold boom of the 18th century. Belo Horizonte's municipal system has some 164 primary and 26 secondary schools $^{3}$, as well as pre-school, special education and youth and adult education provision (INEP 2007). 
The PS, initiated in the 1990s by the Municipal Secretariat of Education (SMED), is not so much a project or programme as a framework of policy and practice. The central principle on which the PS is based is inclusion. The traditional school is seen to exclude sections of the community in a number of ways: through its choice of valued knowledge, its assessment procedures, the structure of the school day and the teacher-student relationship. The framework, therefore, represents an opening of this rigid system to a plurality of individuals, groups and cultures, giving each equal value and opportunity.

In particular, the PS aims to combat 'school failure', represented by dropout and repetition (pupils traditionally repeat the whole school year if they do not reach the test level of $60 \%$ ). Repetition leads to many individuals, and certain social groups in particular, being unable to complete primary school and, as a likely consequence, to their systematic exclusion from valuable living in society. The principles underlying the framework are well expressed by Castro (2000: 3):

Initially, 'school failure' seemed to reveal the inadequacy of pupils in school, which ended up legitimising their social exclusion. Incapable of proceeding in their studies - exposed to multiple exam failure and repetition which led, in many cases, to dropout - pupils (and their families) gradually internalised the exclusion and made it legitimate as an expression of their individual incapacity or difficulty of adaptation. The right to education, seen simply as the right to access to school, became then the social form of legitimising exclusion.... It was understood that it was necessary to construct a new order of school capable of ensuring the inclusion of all, particularly those sections of the population that were systematically excluded and/or marginalised, guaranteeing them not only access to formal education, but above all the possibility of participating in the construction of new knowledge and the acquisition of knowledge produced throughout the history of humanity ${ }^{4}$.

The distinctive feature of the PS, therefore, is its recognition that the realisation of the right to education can be a form of exclusion if attention is not paid to processes within the school. Implementation of this vision, however, is not without challenges. Existing research (e.g. Dalben 2000; Glória \& Mafra 2004; Soares 2001) shows these difficulties, particularly in relation to misunderstanding of and resistance to the initiative by teachers, students and the local communities.

\section{Approaches to school democratisation}

The importance of pupil participation in the PS framework is shown in the following statement:

[A]11 [the politico-pedagogical plans] propose the development of the citizen for participation in society. All these proposals note that school will develop these collective subjects in as far as they make them participants in the construction of humanised school spaces. (SMED 2002: 15) 
The development of democratic citizenship, therefore, depends on the democratic culture prefigured in the schools. The fact that this involves more than classroom activities was emphasised by Dora ${ }^{5}$, deputy head of Barroso School:

I think that it allows us every possibility for working with the question of citizenship. First because it requires a democratic school and a school which can and must create opportunities so that children can acquire this notion of what citizenship is.

Ermenegilda, headteacher of the same school, supported this view:

I think that in general, the first thing is to call the pupils to participate in all the... deliberative instances of the school, you see, the first thing is that he [sic - the pupil] knows that the school is a place to position himself...

What is required, therefore, is both a school that embodies the democratic principles it aims to promote, and one that provides particular opportunities for citizen learning. There are a number of bodies in which pupils participate. The School Assembly, with the participation of the whole school community, has the function of making decisions on key issues such as arrangements during a teachers' strike. The smaller 'School Council' (clearly distinct from that seen in the UK), with student, teacher and community representatives, has a more executive role, with responsibilities including management of the budget. While there are federal, state and municipal guidelines on the curriculum, individual schools have a large degree of leeway regarding what is taught. Schools, therefore, construct their own distinctive 'politico-pedagogical plans', which provide the basis for the curriculum. Direct elections for headteachers are also universal in the municipal network, aiming to make school leadership more responsive to local needs and political demands. The participation of students, therefore, takes place in the context of a wider democratic basis for schooling, involving teachers and communities as well. This participation is primarily a right of those groups involved to have a say in matters that affect them, but it is also seen as a learning experience.

In relation to this participation, the 'collective' is an ever-present notion: "In the school as a whole, it is indispensable to have collective work, in which teachers of different cycles, of different classes are together, discussing, reflecting...." (SMED 2002: 66). For students there must be opportunities for "interaction between learners in a truly group experience, where they can adopt different roles..." The Barroso School document (2004: 28) states:

[E]ducational institutions should enable a process of collective participation, producing concrete examples of democratic actions which go beyond their walls, which reach out, profoundly and visibly, intervening in an effective way in the formation of citizenship.

Later in the document some concrete examples are proposed: 
It is necessary to continue calling the pupils to participation. Participation as an integral part of the school community, with co-responsibility, commitment and interaction between the different instances of the segments involved in democratic management, through the incentive to the creation and integration of grêmios, newspapers, radios and pupil assemblies.... (p.29)

The grêmios are pupil associations, elected by the pupils themselves, which organize cultural, sporting and political activities in the school and act as a forum for discussion and as a mouthpiece for student views. These are not original to the PS framework, and have a long history in Brazilian schools, yet the municipal government has aimed to give them impetus, and importantly to change their nature, so that they move away from being mere organizers of sports days and parties and become an effective force for the development of active citizenship among the student body. They customarily have an organising committee of up to a dozen students, with a leader and deputy, but involve much greater numbers at meetings and events.

A key aspect of the participatory culture in PS schools, and one which serves to differentiate it from other efforts at school democratisation, is that it is embedded within a commitment to transforming political relations. This is contained particularly in the adherence to Freirean dialogue as a pedagogical principle. Dialogue, in the Freirean sense, involves a radical alteration of the relations between teacher and student, and of the process of knowledge construction and acquisition (Freire 1972). In Barroso School (2004: 14), for example, there is a commitment to "increasingly horizontalised relations" being established. Teachers are to be:

agents, real subjects of their own pedagogical action as programmers, producers of alternative pedagogical materials, researchers of their own work, as inquirers who in every moment problematise their practice and deepen their theoretical reference points. (SMED 2002: 66)

With both students and teachers as empowered agents, a new relationship is established on the basis of dialogue:

It is necessary that a dialogical relationship is established in the classroom, where all can put ideas forward, ask, exchange, negotiate meanings, share. It is necessary to break with the monological pedagogy in which only the teacher speaks.... (SMED 2002: 66)

The PS approach, therefore, is one in which the specific opportunities for pupil participation in decision-making -- such as the School Council and grêmio -- are underpinned by a commitment to democratic teacher-student relations and Freirean dialogue.

Challenges of implementation 
The above discussion refers to the ideals of the initiative, and, as would be expected, obstacles were encountered in the process of implementation. Nevertheless, some significant instances of prefigurative forms were observed in practice, and were seen by the students as important learning experiences for them.

While there were a number of structures through which students could participate, the grêmio was the most prominent in the data. Luciana, coordinator in the SMED, gave a positive assessment of the grêmios:

We are seeing a strengthening of the grêmios...Some very much had a sporting or very cultural character.... But what we have seen is a politicization of these grêmios so they come with other discussions that come to question and intervene in the functioning of the school....

Students strongly engaged in the grêmios reported significant political development. Thaís, head of the grêmio in Bandeirante School, described the process of broadening her understanding of political issues as a result of her participation:

The grêmio campaigns for things for the school, for example, you see there's a teacher missing. Ah! You complain to the head. But it's not the fault of the head that there is a teacher missing, that the desks are broken, that there aren't enough materials. Ah! There aren't enough funds. Why aren't there enough funds?... It's a national problem. You begin to see that the structure of society is much bigger. So we begin to get involved in larger issues than this, not only in the grêmio.

For Sueli, in Barroso School, the experience was also one of widening horizons, and seeing one's personal difficulties in a wider context: "The world, it's much bigger, there are many more people, there are many more problems". Sueli's participation in the grêmio led her to attend the World Social Forum in Porto Alegre along with a delegation of teachers from the city.

Silvia, another committee member of the grêmio in Bandeirante School, also commented on various qualities gained: "You can't see something and stay quiet any more. You change completely. You also learn to administrate, very big responsibilities.... You learn to live with others, to speak in public." Thaís also spoke of public speaking skills: "I didn't use to say anything. I used to arrive in the classroom and I was shaking a lot... Now I go to the Federal University and I speak to the students without any problem."

Silvia commented on how participation in the grêmio requires a 'public' understanding of and working with others, across their 'private' differences:

...you have to live with difference in the grêmio because you have people of all types. You can't arrive and say "you won't participate because I don't 
get on with you". So it's like that, you have to end up separating the personal act from that. The grêmio is for everybody.

However, while students like Thaís and Silvia had very rich processes of political development, they are not representative of the whole pupil body. Although now in a state school, Thaís had previously attended a private school, and came from a supportive family background. It is not clear how much these structures facilitate the participation of students from more disadvantaged backgrounds, and whether learning experiences are provided for those outside the leadership.

In line with the findings of research in the UK (e.g. Maitles \& Deuchar 2006) that positive attitudes towards school councils are largely confined to those directly involved, students in Barroso School who did not participate directly in the grêmio associated it principally with organising parties and excursions (although they saw the school radio as an important way of keeping students informed). They expressed scepticism about its political nature, and its efficacy in giving a voice to student views. This opnion was supported by Dora, who, despite being a strong advocate of the grêmio, admitted that, "... of course it's not the majority of the pupils". Sueli attributed the lack of participation to negative attitudes on the part of those not involved:

Because, the people, it's not important for them, they think it's us that are working to improve things... they live in their own little worlds and they don't mind about other things, so it's complicated ... to be participating, it's difficult. These people aren't even participating in their classes, let alone the grêmio.

However, problems may equally well lie in the ways in which the grêmio makes itself accessible and engaging for all. As well as difficulties in extending participation to all within the school, there were also divergences between schools. At Cantagalo School the grêmio was almost nonexistent:

TM: Is there a grêmio in the school?

Pupil 1: Ah. I've heard there is, though I've never seen it.

Pupil 2: There is a grêmio, but I've never seen their proposals, there isn't even an election....

Pupil 3: You see, they organised a time for meeting that was only convenient for the organising group, it wasn't for other people in the school.

However, taking a perspective broader than participation in the grêmio, there was evidence of a general increase in student participation in decision-making. Dora believed strongly that the students in her school had undergone a process of political empowerment: 
I see that with every year that passes...I don't know if it's because of our way of dealing with the children, we're not passive at all. Our pupils are very determined, our pupils question, our pupils go after what they want.... But I see every year us forming pupils, or at least a group of pupils, who leave here more aware, who have political positions....

This view was supported by the SMED coordinator Kelly:

You go into school and there are teenagers, young people, who speak, who stand up for themselves, who claim their rights, who have strategies of resistance that you can't even imagine.... So it's necessary to listen to this, because they're saying something.

Dora related the story of one student who had left the school to become president of the Municipal Students Union of Belo Horizonte, participating in student political activities at the national level. In Dora's view, there is a strong link between democratic processes in the school and political participation outside it, between the prefigurative and the prefigured:

So I see that a good proportion of our students manage to understand and live that democracy and then live it outside. Because if it is lived in the school... if he [the pupil] manages to participate in the life of the school where he is seen as a citizen with rights, he can exercise these rights here in the school, and that implies duties too. For him it seems clear to have that role outside, to be an aware citizen.

In relation to gender, the initiative was successful in overcoming disparities of political influence in the wider society. Girls were more prominent than boys as representatives in decision-making bodies (such as the grêmio), and were as participatory in class as boys. Both focus schools had female headteachers, and in general, girls had female role models not only in relation to classroom teachers but also in positions of responsibility in school and local authority.

As seen in the UK context, student action was restricted in part to deciding relatively trivial elements of school rules, such as their not wearing uniforms, and being able to leave the school in lunch times. Yet at times it also extended to the curriculum. Segundo pointed to the empowerment of his students to critique his own teaching:

So they have a strong critique of my classes. So if I enter into any contradiction, they stop me there and then, something that I think is great, it's a problem that I created, a problem that is great, because I see that they contest things, they don't accept passively everything that I say.... [B]ecause often the pupil sees the teacher as the master of knowledge.

Even three students who were not active participants in the gremio emphasised the change in power relations: 
TM: Do you think in general the voice of the student is heard?

Pupil 1: It has more weight than the voice of the teacher I think.

Pupil 2: Yes, it's because the students are in the majority.... one or other voice doesn't count for much, but the voice of the people I think it has more power than the voice of the teachers themselves, of the headteacher.

Pupil 3: And also we can demand things, what we want, we can ask for our rights, you see.

TM: And do you manage it?

Pupil 2: We even get rid of teachers who aren't teaching properly.

While the pupils have perhaps overstated their influence in relation to teachers here, the key point is the perception of their right to power in the school. Not surprisingly, teachers were a little nervous about this growing student influence, and about the evaluations of them that the students were beginning to carry out in some schools. As Kelly stated:

The school's not the same is it was years ago. The school's more democratic, the pupils are freer. But this also causes other problems, because we teachers aren't very used to this more democratic way of doing things.

So, while participation in the grêmios may have been limited, there was evidence of a significant shift in power relations in the schools, and empowerment of the students.

In addition to processes within the school, there were instances of direct political participation outside. Students in Barroso School were active in these forms of participation:

We worked in a building much worse than this...the children mobilized themselves, a group of teachers and pupils.... They went to the street, they closed off the street, there were politicians there, there was a really strong participation and afterwards...we managed to get the funds through the participatory budget from the city council with a big mobilization of these pupils. (Interview with Ermenegilda)

Ermenegilda was also positive about the proportion of students involved: "It depends, in something like the street mobilization...a great mass of people went...the majority of them". Although she added that she was referring to the older students here, not the lower years. "Even those who don't participate actively, they have an idea what's going on, and they participate directly when we call them to a council to resolve something". 
Student campaigning was also instrumental in getting soundproofing from traffic noise for the school. Another campaign was mounted in order to make up the shortfall in teachers. This protest led to students being arrested, and the consequent publicity put pressure on the SMED, who on the very next day provided extra teachers. Dora stated in relation to this incident:

What did it need? It needed our pupils to get hit and go to prison. Pupils under 18 years of age to be arrested and to go in a police van with handcuffs and everything. But have they had a better citizenship class? I think they haven't.

In summary, there was evidence of widespread democratisation of the schools in question, with students becoming more aware of their rights and able to articulate them. In formal structures like the grêmio, however, participatory experiences were very rich for some, but limited to a small number of people and there was disparity in the introduction of these bodies across the school system. Importantly, participation in the school context led on to political action outside.

\section{The Landless Movement}

The Movement of Landless Rural Workers $\left(\mathrm{MST}^{6}\right)$ is widely recognised as the largest and most influential social movement in Latin America. It grew out of the actions of scattered rural uprisings and progressive wings of the Catholic Church responding to the urgent need for agrarian reform (Forman 1972). In Brazil, approximately 1\% of landowners control $50 \%$ of farmland, while there are as many as 4.5 million landless peasants (Brandford \& Rocha 2002; Caldart 2000). The movement was officially founded in 1984 and functioned initially in the south of the country, although now it has spread to 23 of Brazil's $27^{7}$ states.

The general aims of the movement are:

1. To build a society without exploitation where labour has priority over capital.

2. To ensure that the land is at the service of all in society.

3. To guarantee work for all, with a just distribution of land, income and wealth.

4. To strive constantly for social justice and equality of rights, whether economic, political, social or cultural.

5. To encourage humanist and socialist values in human relations.

6. To combat all forms of social discrimination and promote equal participation for women.

(MST 1995)

Central to the movement's activities is land occupation, whereby a group of families squats on unused agricultural land in one of the large estates. An acampamento (camp) is formed, in which high levels of organisation and co-operation are required to sustain the itinerant community. If the families win the right to stay, the acampamento then becomes 
an assentamento (settlement) and they can begin to farm their own land, which they do either individually or collectively.

Soon after the first settlements were established it became clear that some form of educational provision would be necessary for the children of the landless. Furthermore, a large proportion of the adults were themselves illiterate and needed to develop basic skills to improve their agricultural work and enable effective political participation. A few primary schools emerged, along with adult literacy classes, staffed mainly by those few members of the community who had completed school. After struggles with local authorities, communities managed to have their schools officially recognised, and thereby gain state funding and provision of teachers and materials. Education soon became a key priority for the movement, and today there exists a network of 1,500 schools ${ }^{8}$ which have provided for 160,000 children, many of whom otherwise could have expected no more than a few years of poor quality primary education (MST 2004). There are also many thousands of students in youth and adult education, and provision in pre-school education, technical secondary courses, and other HE courses in partnership with established universities. The first formal teacher education courses at secondary level were run in 1990, and in 1998 a higher education programme for teachers was established, using a distinctive approach termed pedagogy of the land. This study, however, will focus on primary and secondary schools.

These quantitative gains are significant in themselves. Yet the aim of the MST is to transform the fundamental nature of education as well:

Faced with the tradition of an elitist, authoritarian, bureaucratic, content-heavy, 'banking," school, with a narrow and pragmatist conception of education, [we have] the challenge of constructing a popular, democratic, flexible, dialogical school, a space for a holistic human development in movement. (MST 2004: 15)

In this process of pedagogical transformation, the key influence is Paulo Freire, but the movement also draws on educationists such as Jose Martí and Anton Makarenko. One core element is that education in the MST is organically linked to the social movement and the community in which it is based (Caldart 2000). It also contributes to the development of the sem terra (landless) identity, which is seen to be fundamental to the development of the social movement as a political actor.

\section{Approaches to school democratisation}

Participation for the MST is linked to the Freirean notion of becoming 'subjects of history', of having the capacity for transforming the world, and being aware of that capacity. Freire $(1972 ; 1994)$ understood the state of oppression to involve a false understanding that the individual has little or no control over destiny, and liberation to involve a realisation of the dependence of external reality on internal thought and activity, leading to transformatory action. As Vicente (headteacher of Treviso School) 
stated, education must help form people who are, "Subjects of their own history, profoundly knowledgeable of their own reality and able to intervene in that reality".

In accordance with this commitment, a fundamental principle of MST education is that the students are fully involved in the educational process, not only in terms of expressing their views in the classroom, but also of being involved in the processes of decisionmaking within the institution:

The big and even the little activities of day-to-day life in the school must be planned collectively.... Where the planning is concentrated in a few heads (from top to bottom) there is no democracy.... (MST 1995: 8)

The most radical examples of student participation are seen in the MST teacher education courses (Caldart 1997), but is it is also backbone of primary education (McCowan 2003). The schools have a number of participatory structures, some of which are the same as those seen in the context of the PS. Although these features depend on municipal or state legislation, ideally there is election of headteachers and a school council. The latter is the highest body of management, with responsibilities for financial resources, the school calendar, accountability, elaboration of the politico-pedagogical plan, and guaranteeing the responsiveness of the council to the wishes of all members of the community (e.g. Salinas School 2002: 14). Students participate in the election of head teachers and have representatives in the school council.

The participation of students must be seen as part of an approach to management and curriculum construction which involves all members of the school and the local community (Treviso 2003: 31). Some schools have horizontal management structures with the responsibilities of headteacher rotating among the members of staff. In Salinas School (2002: 9), students, teachers, non-teaching staff and senior management are supposed to have time set aside each week for collective evaluations, which are then sent to the general assembly for ratification. Students within their classes are encouraged to organise class councils, assemblies, establish classroom rules, evaluate the educational process, propose voluntary work and debate the directions of the school (Treviso 2003: 32). Elaine, headteacher of Salinas School, stated:

Our class councils are participatory: parents, students, teachers and senior management all participate.... So this is the moment where the students can make their evaluation of the educational process of the school, of its performance.

Students are also intended to organise themselves within their 'work teams'. Time is set aside in the school day for them to engage in cooperative work such as tending to the vegetable plot and flowerbeds. The work undertaken both inside and outside school serves to foster positive rural values and identity, and for them to gain skills and knowledge in agricultural techniques. This serves: 
[T]o break the individualist culture in which we are submerged, through new relations of work, through dividing tasks and thinking of the welfare of all the families, and not everyone for him or herself. (MST 1999b: 7)

As in the PS, dialogue forms one of the non-negotiable pedagogical principles on which MST educational activities are built. In the case of the MST, this has a more explicitly political orientation, forming part of the creation of an egalitarian socialist society. The Freirean influences in MST pedagogy can be seen in the following statement:

From our pedagogical practices we could verify the truth of the principle that says: no one learns through somebody else, but also nobody is educated alone.... [I]t is not only the teacher-student relationship which educates: it is also the relationship between students and between teachers.... Everybody learning and teaching amongst themselves.... The collective educates the collective. (MST 1999a: 23)

The Salinas School programme (2002: 8) states:

Research and not learning for repetition is emphasised, aiming for the collective construction of knowledge and encouraging the student to learn to find solutions and make new discoveries. Dialogue makes viable the participation of the students in the school and in the struggle for a dignified life, building their identity, as well as knowledge.

There are other forms of active political development aside from these instances of pupil self-organisation. The MST is emphatic that 'education' cannot be confined to schools:

But it is good to bear in mind that the pedagogy which forms new social subjects, and which educates human beings, goes beyond the school. It is much bigger and involves life as a whole. Some educational processes which sustain the Landless identity could never be realised within the school. (MST 1999b: 6)

Part of this concerns community outreach. MST (1999b) recommends a number of ways in which students should make contact with the community via the school, including organising cultural activities and contributing to the preservation of community history. The document also proposes visits to other settlements, camps, schools, cooperatives and historical sites (MST 1999b: 43). In addition, Treviso School proposes the organization of 'pedagogical camps', "to recover the history of the families and continue the discussions about this school we want".

However, the MST is distinctive in its encouragement not just of community involvement but also political activity at local and national levels. Examples of this form of activity are participation in the occupation of land and establishment of acampamentos, occupation of public buildings, and participation in protest marches. The presence of these activities, and the participation of students in MST mobilizations are justified by the 
need to "provide students with the means to widen their horizons, thereby allowing a different reading of their own reality" (MST 1999b: 43). In view of the importance of activities conducted outside the school, the MST (1999b) urges schools to organise themselves in such a way that students are not disadvantaged through possible absences, and that the experiences outside the school are shared with the other students.

The MST, therefore, with a more clearly defined political orientation than the PS, aims to form 'subjects of history', through the formation of democratic structures in schools and opportunities for collective work and political action.

\section{Challenges of implementation}

Aline, a 14-year-old student, who had studied in other schools in the local town, gave a good indication of the distinctive atmosphere of an MST school:

I think that if I continued...studying at that school, I wouldn't think in this way.... It's like they, they don't teach right, you know. They don't want the children to have a clear vision of what's happening in the country.... And here in the [MST] school, it's different. Here in the school you can speak to teachers in the hallway. You can say what you think, you can ask anything about politics and the political parties and so forth.... That's why, that's why I like it here more. I think that this school made me grow a lot as a person.

Deputy headteacher Horácio supported this view, speaking of students who had gone on to study in other schools:

So they complain... "There in our school we could give our opinion, we could change things, we could participate, we could influence and so forth and there not, there they don't let us do anything"....

The headteacher Ruth in Salinas School spoke of the way the class council enabled students to resolve their own problems of disputes and disruptive behaviour. Raiza, the student representative at Treviso School, related that the voice of the students was increasingly heard in relation to the facilities and decorations in the school. Yet, more impressively, she stated that the students had been able to bring changes in teaching styles (" the way the teacher explains things"), particularly in the case of one teacher whose style was rather abrupt and unfriendly. She is an example of someone who had developed considerable levels of knowledge and skills through her role in the school (although not all pupils had such an active role).

These spaces for decision-making were observed in practice. In a 'self-organisation' class in Salinas School, the students (in this case all female) were deciding how to raise money in order to pay for a school trip to a theme park. Significant skills of self-organisation were observed, in terms of discussion, decision-making and recording of the meeting. While one of the students had a lead role in the discussion, all seven of them made 
contributions and were listened to. At some points, voices started to be raised and more than one discussion was underway at the same time, but usually one of the students said "one at a time", and order returned. Agreements on each particular topic were reached only after lengthy discussion and consideration of a number of different possibilities.

Salinas School has two representatives for each class who meet once or twice a month with the headteacher and deputy to discuss student issues. According to Horácio, "they have total freedom to criticise the leadership of the school". However, there were some limits on student influence. Aline describes her experience as class representative in the following way:

Aline: So they [the head and deputy] held a meeting, to see everything that we wanted to change in the school. So we [the students] sat in the classroom, we set aside some time, half an hour.... Everyone said what they wanted, so we noted it down and took it to the meeting and discussed it with the teachers there. It was like that.

TM: And did you manage to change anything?

Aline: Yes, we did, we got them to ring the bell for break earlier [laughs]

This does represent a form of student victory, but, as indicated by the student's reaction, it is not evidence of a real change in the power relations. The limitations of student power are backed up by comments by the younger children at Salinas School:

Pupil 1: They have a meeting, and we put forward everything, like, the problems of the class. We speak, we discuss everything and gradually find a solution to the problems of the class.

TM: Do they do what you ask for?

Pupil 1: If it's something okay, here inside which is possible without much problem, then they do it.

Pupil 2: But not everything!

Pupil 1: Now if we expect something more, I mean, out of than normal, then that won't do.

TM: $\quad$ Can you give an example of the types of things you ask for in meetings?

Pupil 3: Like, we ask for the day that we're going to celebrate the June festival. 
In restricting student action to recreational events, therefore, the structures for student representation can at times be little different in practise from the limited form of grêmio discussed in the context of PS.

Another significant space for pupil self-organisation was the work teams, where students developed skills and values of collective work and ownership of the school space. In addition to these, pupils took responsibility for cleaning their classrooms at the end of the day. There was a naturalness, efficiency and even enjoyment with which the students tidied and swept their room after the bell went in Treviso School.

In relation to the gender dimension of participation, as in the PS, classroom observation showed equal or greater participation of girls than boys in discussions, and proportions of girls in representative positions were higher than those of boys. While there were cases of stereotyping of gender roles, in general MST schools were challenging the low representation of women in positions of political power in the wider society.

In reality girls participate much more than boys do. This is true. Principally we perceive this in the process of working in the school that girls are more aware. They incorporate it as something important and participate more. For boys, in adolescence, they're more estranged from this. (Interview with Vicente)

The strong participation of girls was particularly surprising given the machista values of traditional culture in Rio Grande do Sul.

The schools were also engaged in political activity beyond their gates. A form of protest commonly referred to in the two schools was that of Independence Day. Instead of glorifying the Republic, they used the traditional marches to critique the injustices of the country and promote the cause of land reform. According to Marco:

So this day the $7^{\text {th }}$ September is no longer just to march, it has become for us a day of struggle to show our indignation, I mean, to show our schools, what we have, what we have achieved in the settlements of agrarian reform and because of this we've suffered quite a lot, how can I explain, this negligence of the government which puts out in the media that this is an attack, that this is educating people to cause unrest in society.

In a similar way, a drama presentation was prepared in Treviso School for the celebration of the founding of the local town. One of the pieces told the story of the establishment of the Treviso settlement, seen through the eyes of a single family. This formed part of the community's ongoing efforts to make the inhabitants of the local area understand the struggle.

The headteacher Ruth also highlighted political action outside the boundaries of the school. The first example was visits to the MST camps: "Students go there, experience 
life in the camp, exchange experiences with the children, do workshops, so this is very strong". She also highlighted participation in the movement's mobilisations:

The school does not distance itself from this struggle. Children initiate campaigns ... the school is in constant movement. Always campaigning for teachers, for the quality of school transport, the widening of the civic space, our children are always in this debate.

During the period of research, students at Salinas organised their own protest at the town hall to obtain reliable transport to and from the school.

Pupil participation in the MST, therefore, is strong in relation to the community's collective construction of the curriculum and in instances such as the work teams. There are also democratic representative bodies, although these encounter limitations on their power in practice. Schools have a very strong engagement with political action outside.

\section{Towards a prefigurative conception}

The experiences outlined above have highlighted some important questions in relation to pupil participation in schools. Firstly, it seems vital that representative bodies for pupils are embedded in a deeper democratisation, involving fundamental aspects of teacherstudent relations and decision-making over teaching and learning, in conjunction with participatory structures for teachers and the local community. This is important in order to avoid fragmented instances of pupil participation leading to trivialisation and tokenism. It is also important that democratic experiences within the school are linked to wider political action outside it. Lastly, the democratisation must be based on a vision of social transformation, rather than the insertion of young people into a rigid and unchangeable political and economic system.

The two cases explored here illustrate in different ways the three aspects of prefigurative forms identified above. In the first place they are instantiations of the new society: in the case of the MST a community working together to overcome the individualism and fragmentation of capitalist society and building relations based on equality and solidarity; in the case of the PS, an arena of inclusion where differences are valued and all have the chance to achieve and have their voices heard. They are also sites for learning, through the experiencing of these new forms of relation, and the development of knowledge, skills and values for participation. Lastly, they are examples of how alternatives can function in practice, providing lessons and inspiration for others.

However, as shown above, these initiatives are not without their problems. There is always a risk of representative bodies channelling student demands towards unthreatening areas such as recreation times and clothing, rather than curriculum and management. Increases in pupil influence also threaten the positions of teachers, who can serve -- either actively or by default - to dampen down the changes. In addition, the initiatives have other challenges of implementation -- such as gaining the active support 
of parents and local communities -- that this article has not been able to address. Nevertheless, they serve to illustrate an orientation for pupil participation that goes beyond tokenistic forms and instrumental, non-democratic rationales. Further research is needed to understand and disseminate these forms of initiative.

A number of complex questions, however, are raised by the fact that prefigurative forms exist within wider social contexts that at best are unsupportive, and at worst, hostile to them. One thing that distinguishes an educational initiative from a political organisation is that the former is almost always a temporary experience. In the case of the PS, for example, it is not clear how well equipped the students will be when they emerge from the inclusive school into the exclusive wider society. This raises the difficult question of the extent to which schools should prioritise being special democratic arenas in themselves, or acting as transformatory spaces in relation to the wider society. While these two aspects appear to be complimentary, they may be in tension, if, for example, students experiencing a highly democratic environment do not acquire the knowledge and skills needed to engage in the oppositional, conflictual politics needed to bring change in a semi-democratic or undemocratic society.

There is also the tension between democracy as a procedure for decision-making and as a set of values, as highlighted by Apple and Beane (1999: 10-11):

It is one of the contradictions of democracy that local, populist politics do not always serve democratic ends... [T] he realization of democratic schools does in part depend on selective intervention of the state, especially where the process and content of local decision making serve to disenfranchise and oppress selected groups of people.

The 'reigning in' of local decision-making on the basis of 'higher' democratic principles seems to negate the right to participate, and yet allowing anti-democratic policies to be established on the basis of democratic decision-making is also ultimately self-destructive. In fact, the cases here were far from showing instances of the sort alluded to by Apple and Beane (e.g. racial segregation or restriction of access to the wealthy), but an extension of pupil and community control in the Plural School may indeed lead to some degree of undermining of the initiative itself, given the reservations in relation to transformations of curriculum and assessment.

A further question arises in terms of the viability of initiating these educational forms in other contexts. Brazil is a country of extreme socioeconomic inequalities and injustices, but it does allow space for the creation of educational and political alternatives at the local level. It is unclear whether similar initiatives could emerge in the stifling atmosphere of an education system like that of the UK (aside from small experiences at the periphery like Summerhill). Nevertheless, a commitment to the prefigurative means that attempts must always be made to construct new forms of living in the here and now, rather than waiting for social transformation at some point in the future. 


\section{Notes}

\footnotetext{
${ }^{1}$ It is not being suggested that the authors cited here necessarily endorse these rationales, only that these works illustrate them.

${ }^{2}$ In the case of the Plural School, there is also reference to a third school (Bandeirante) in which initial research was carried out.

${ }^{3}$ Primary school in Brazil is usually of eight years in duration, corresponding to the 7-14 age group. Secondary school is only three years, from 15-17. However, there are high rates of repetition, so many students are older than the official ages. A number of institutions have both primary and secondary provision on the same site.

${ }^{4}$ All translations from Portuguese are the author's.

${ }^{5}$ Pseudonyms have been used for all individuals and schools. The names of the initiatives and the regions in which they are located are real.

${ }^{6}$ Movimento dos Trabalhadores Rurais Sem Terra

${ }^{7}$ This figure includes the Federal District.

${ }^{8}$ Most of these schools are small in size. Only 200 have the complete eight grades of primary school, and only 20 have secondary provision (MST 2004).

9 i.e. Freire's (1972) conception of 'banking education'.
}

\section{References}

Apple, M. W., and Beane, J. A. (Eds.) (1999) Democratic Schools: Lessons from the Chalk Face. Buckingham: Open University Press.

Baginsky, M. (1999) School councils: the views of students and teachers. London: NCPCC.

Barroso School (2004) I Congresso Político Pedagógico: Democracia, Ética e Inclusão. Internal document.

Barroso School (2001) Rede de Trocas (3o Caderno). Belo Horizonte: SMED.

Bartlett L. (2005) Dialogue, knowledge, and teacher-student relations: Freirean pedagogy in theory and practice. Comparative Education Review, 49 (3), 344-364. 
Boggs, C. (1978) Marxism, prefigurative communism, and the problem of workers' control. Radical America, 11/12, 1: 99-122.

Brandford, S. and Rocha, J. (2002) Cutting the Wire. London: Latin American Bureau.

Breines, W. (1982) Community and organization in the New Left, 1962-1968: the great refusal. New York: Praeger.

Buechler, S. (2000) Social movements in advanced capitalism: the political economy and cultural construction of social activism. Oxford: Oxford University Press

Caldart, R.S. (2000) Pedagogia do Movimento Sem Terra: a Escola é Mais que Escola. Petrópolis: Editora Vozes

Caldart, R. S. (1997). Educação em Movimento: Formação de Educadoras e Educadores no MST. Petrópolis: Editora Vozes.

Castro, M., C., P., S. (2000) Escola Plural: a Função de uma Utopia . Paper presented at the $23^{\text {rd }}$ Annual Meeting of the National Association of Educational Research and Graduate Studies (ANPED), Caxambu, Brazil, 24-28 September.

Cox, S. and Robinson-Pant, A. (2006) Enhancing participation in primary school and class councils through visual communication. Cambridge Journal of Education, 36 (4), 515-532.

Dalben, A. I. L. de F. (Ed.) (2000) Avaliaçao da Implementação do Projeto PolíticoPedagógico Escola Plural. Belo Horizonte: GAME/FaE/UFMG.

Epstein, B. (1991) Political protest and cultural revolution: nonviolent direct action in the 1970s and 1980s. Berkeley: University of California Press.

Epstein, B. (1988) Politics of Prefigurative Community: the Nonviolent Direction Action Movement. In M. Davis \& M. Sprinker (Eds) Reshaping the US Left: Popular Struggles in the 1980s. London: Verso.

Evans, S. (1979) Personal politics: the roots of women's liberation in the civil rights movement and the New Left. New York: Knopf.

Fielding, M. (2007) On the necessity of radical state education: democracy and the common school. Journal of Philosophy of Education, 41 (4), 539-558.

Fielding, M. (1997) Beyond school effectiveness and school improvement: lighting the slow fuse of possibility. Curriculum Journal, 8 (1), 7 - 27. 
Fischer, M. C. B. and Hannah, J. (2002) [Re]constructing Citizenship: the Programa Integrar of the Brazilian Metalworkers' Union. In M. Schweisfurth, L. Davies and C. Harber (eds.) Learning Democracy and Citizenship: International Experiences. Oxford: Symposium.

Flutter, J. and Ruddock, J. (2004) Consulting Pupils: What's in it for Schools? London: RoutledgeFalmer.

Forman, S. (1972) Disunity and Discontent: a Study of Peasant Political Movements in Brazil. In R. Chilcote (ed.) Protest and Resistance in Angola and Brazil. Berkeley: University of California Press.

Franks, B. (2006) Rebel alliances: the means and ends of contemporary British anarchisms. Edinburgh: AK Press.

Franks, B. (2003) Direct action ethic. Anarchist Studies, 11 (1), 13-41.

Freire, P. (1994) Pedagogy of Hope: Reliving Pedagogy of the Oppressed. New York: Continuum.

Freire, P. (1972) Pedagogy of the Oppressed. London: Sheed and Ward.

Gandin, L. A. (2006) Creating real alternatives to neo-liberal policies in education: The citizen school project. In M. W. Apple and K. Buras (Eds.), The subaltern speak: curriculum, power, and educational struggles. New York: Routledge.

Gentili, P., \& McCowan, T. (Eds.). (2003). Reinventar a Escola Publica: politica educacional para um novo Brasil. Petropolis: Vozes.

Ghanem, E. (1998). Social Movements in Brazil and their Educational Work. International Review of Education, 44(2-3), 177-189.

Glória, D., M., A. \& Mafra, L. de A. (2004) A prática da não-retenção escolar na narrativa de professores do ensino fundamental: dificuldades e avanços na busca do sucesso escolar. Educação e Pesquisa, 30 (2), 231-250.

Gordon, U. (2007) Anarchism reloaded. Journal of Political Ideologies, 12 (1), 29 - 48.

Gordon, U. (2005a) Anarchism and political theory: contemporary problems. Unpublished PhD thesis, University of Oxford.

Gordon, U. (2005b) Liberation now: present-tense dimensions of contemporary anarchism. Paper presented at the Graduate Student Conference "Thinking the Present : The Beginnings and Ends of Political Theory", University of California, Berkeley, 27-28 May. 
Gribble, D. (1998) Real Education: Varieties of Freedom. Libertarian Education

Harber, C. and Trafford, B. (1999) Democratic management and school effectiveness in two countries: a case of pupil participation? Educational Management and Administration, 27 (1) 45-54.

Inman, S. and Turner, N. (2007) Researching cultural harmony through the student voice. Education, Citizenship and Social Justice, 2 (2), 119 - 133.

King-Calnek, J. (2006) Education for Citizenship: Interethnic Pedagogy and Formal Education at Escola Criativa Olodum. Urban Review, 38 (2), 145-

Li, H.-L. (2005) Rethinking civic education in the age of biotechnology. Educational Theory, 55 (1), 23-43.

Macbeath, J. and Moos, L. (2004) Democratic Learning: the Challenge of School Effectiveness. London: RoutledgeFalmer.

Maitles, H. and Deuchar, R. (2006) 'We don't learn democracy, we live it!' Consulting the pupil voice in Scottish schools. Education, Citizenship and Social Justice, 1 (3), 249-266.

McCowan, T. (2009) Towards an understanding of the means-ends relationship in citizenship education. Journal of Curriculum Studies, 41 (3), 321-342.

McCowan, T. (2008) Curricular transposition in citizenship education. Theory and Research in Education, 6 (2) 153-172.

McCowan, T. (2003). Participation and Education in the Landless People's Movement of Brazil. Journal for Critical Education Policy Studies, 1(1). http://www.jceps.com/index.php?pageID=article\&articleID=6

McEvoy, L. and Lundy, L. (2007) E-consultation with pupils: a rights-based approach to the integration of citizenship education and ICT. Technology, Pedagogy and Education, 16 (3), $305-319$.

MST (2004) Educação no MST: Balanço 20 Anos (Boletim da Educação no. 9). São Paulo: MST Setor de Educação.

MST (1999a) Princípios da Educação no MST (Caderno de Educação no. 8). São Paulo: MST Setor de Educação.

MST (1999b) Como Fazemos a Escola de Educação Fundamental (Caderno de Educação no. 9). Veranópolis: ITERRA. 
MST (1995) Como Fazer a Escola que Queremos: o Planejamento (Caderno de Educação no. 6). São Paulo: MST Setor de Educação.

Myers, J. (2008) Democratizing school authority: Brazilian teachers' perceptions of the election of principals. Teaching and Teacher Education, 24, 952-966.

QCA (1998) Education for Citizenship and the Teaching of Democracy in Schools. Final Report of the Advisory Group on Citizenship. London: QCA.

Osler, A., and Starkey, H. (2005) Changing Citizenship: Democracy and Inclusion in Education. Maidenhead: Open University Press.

Power, F. C., Higgins, A., \& Kohlberg, L. (1989) Lawrence Kohlberg's Approach to Moral Education. New York: Columbia University Press.

Rowbotham, S. (1979) Beyond the Fragments. London: Merlin.

Ruddock, J. and Flutter, J. (2000) Pupil participation and pupil perspective: 'carving a new order of experience'. Cambridge Journal of Education, 30 (1), 75-89.

Salinas School (2002) Regimento. Internal document.

SMED (Secretaria Municipal de Educação) (2002) II congresso politico-pedagogico da rede municipal de ensinolescola plural (3rd Ed.). Belo Horizonte: SMED.

Soares, C. (2001) A Construção dos Significados da Escola Plural no Universo Docente. Paper presented at the $24^{\text {th }}$ Annual Meeting of the National Association of Educational Research and Graduate Studies (ANPED), Caxambu, Brazil, 7-11 October.

Suissa, J. (2006) Anarchism and Education: a Philosophical Perspective. London: Routledge.

Taylor, M. with Johnson, R. (2002). School Councils: their Role in Citizenship and Personal and Social Education. Slough: NFER.

Treviso School (2001) Projeto Politico-Pedagogico. Internal document.

Ward, C. (1982) Anarchy in Action. London: Freedom Press.

Wolpe, H. (1991) Education and social transformation: problems and dilemmas. In E. Unterhalter, H. Wolpe and T. Botha (Eds) Education in a Future South Africa. Oxford: Heinemann. 
Woodin, T. (2007) 'Chuck out the teacher': radical pedagogy in the community, International Journal of Lifelong Education, 26 (1), 89 - 104. 